\section{Upper Cloud Movements in the Equatorial Regions} of the Atlantic.

I AM sorry that the observations of so good an observer as Capt. D. W. Barker should not agree with my own, but I certainly never confounded what he calls high low-level clouds with the true high clouds.

When clouds are being propagated in a different direction from that in which they are being blown - as sometimes happens - it is exceedingly difficult to ascertain the real direction; but that would not account for the discrepancy between our observations.

My own researches were specially directed to the doldrums, and the history of the Krakatão dust entirely confirms my observations; but in some low latitudes-as in $\mathrm{Cuba}$ - the highest clouds are usually from about south-west. This, however, does not affect the doldrum districts. RALPH ABERCROMBY. 2x Chapel Street.

\section{Fish Dying.}

IN a large pool in this county, well stocked with fish, especially trout and roach, a considerable number of the roach have been found dead every day during the last week. They are in fair condition, and sh w no evidence of poison or of parasitic disease. There is a certain amount of current through the centre of the pool, but the ingress of water has been, of course, much reduced by the drought. The pool, however, covers many acres, and there are twenty feet of water in the deepest parts. Can any of your readers suggest a cause for the death of the roach, and a remedy? No other species appears to have suffered.

Birstal Hill, Leicester, July 4.

\section{THE DINNER TO PROFESSOR TYNDALL.}

THE dinner to Prof. Tyndall, as we stated last week, was going on at Willis's Rooms on Wednesday evening as we went to press. It was attended by as large and distinguished a company as ever assembled to do honour to a man of science. The chair was taken by Prof. Stokes, President of the Royal Society, who had acted as Chairman of the Organizing Committee. Among those who had consented to serve on the Committee were the Marquis of Salisbury, the Duke of Devonshire, the Duke of Argyll, the Right Hon. J. Inglis, the Earl of Rosse, Earl Granville, Sir F. Abel, Prof. Adams, and many others holding high positions in connexion with scientific and learned Societies, and Mr. J. Norman Lockyer and Mr. A. W. Rücker had acted as honorary secretaries to the Committee. Among those who attended the dinner were the Earl of Derby, Earl Bathurst, the Earl of Lytton, Sir F. Leighton, Lord Rayleigh, Lord Thurlow, Sir J. Lubbock, M.P., Sir W. Bowman, Sir F. Bramwell, Sir I. Lowthian Bell, M.P., Sir J. Lister, Sir H. Roscoe, M.P., Sir G. Richards, Lord A. Russell, Sir F. Pollock, Sir Lyon Playfair, M.P., Sir Prescott Hewett, Prof. J. C. Adams, Colonel Donnelly, Sir J. Hooker, Prof. Asa Gray, Prof. Flower, Dr. A. Geikie, Dr. Hirst, Mr. W. Crookes (President of the Chemical Society), Mr. G. B. Bruce (President of the Institution of Civil Engineers), Mr. D. Adamson (President of the Iron and Steel Institute), Dr. J. Evans (President of the Society of Antiquaries), Prof. B. Stewart (President of the Physical Society), Prof. Judd (President of the Geological Society), General Strachey (President of the Royal Geographical Society), Sir J. Fayrer, Sir H. Wilde, Sir H. Doulton, Sir J. Caird, Sir P. Magnus, the President of the Alpine Club, Profs. Frankland, Debus, Tilden, Ray Lankester, Liversedge, G. Darwin, Dewar, M. Foster, Carey Foster, Odling, Gamgee, W. G. Adams, Clifton, Humphry, and Dallinger, Messrs. Warren de la Rue, Gill, Kempe, J. Hopkinson, H. Pollock, E. Wood, Brudenell Carter, Romanes, Pengelly, Preece, Ellis, Vernon Harcourt, R. H. Scott, and others.

At the close of the dinner Mr. Norman Lockyer, at the request of the Chairman, read a list of absentees, from most of whom had been received letters expressing strong sympathy with the object of the banquet, and admiration of the career of Prof. Tyndall. Among the writers were the Marquis of Salisbury, Mr. Goschen, Mr. W. H. Smith, Lord Cranbrook, the Marquis of Ripon, the Earl of Rosse, Lord Monk Bretton, Profs. Max Müller, J. R. Seeley, T. H. Huxley, Sir F. Abel, and about thirty others identified with science and literature.

The first toast was "The Queen," and

The Chairman in proposing it said that the recent celebration of the Jubilee diminished the necessity for saying many words in commendation of the toast. All hearts were affected by the Queen's letter, in which she so touchingly acknowledged the manner in which she had been received. Those who were present at the scene in the Abbey were touched by the exhibition of family devotion and affection which took place at the conclusion of the service, when the Royal Family saluted her who was at the same time Sovereign and mother, and received from her the kiss of affection. And as on that occasion the Royal Family was united with the Sovereign, so on the present occasion, in drinking the health of Her Majesty, they would mentally include the health of the Prince and Princess of Wales and the rest of the Royal Family.

The toast was drunk with all the honours.

The Chairman in proposing the toast of the evening said :- My Lords and Gentlemen,-I now come to the toast of the evening, "The Health of Dr. Tyndall," and may he long enjoy the leisure which he has so well earned. A social gathering like the present is not an occasion on which it is desirable to enter into detail as to the scientific labours of a man, however eminent. Yet the circumstances of the present meeting seem to demand that I should say a few words on some of Dr. Tyndall's researches. Some of his earliest scientific work related to diamagnetism and magnecrystallic action, and in part of this he was associated with the well known German physicist Knoblauch. But I cannot dwell on these now. And I will even dismiss with this brief mention his researches on the properties of ice and his application of them to the theory of glaciers and the observations which he made in common with his friend and colleague Prof. Huxley, whose necessary absence from among us to-night we so much regret. If I be not trespassing too much on the patience of those who listen to me, I would wish to say a little more on that elaborate series of researches, forming no less than six separate papers in the Philosophical Transactions, in which Dr. Tyndall investigated the relation of simple and compound gases and of vapours to radiant heat, especially radiant heat from sources at a moderate temperature. According to his researches, while the main constituents of the earth's atmosphere, nitrogen and oxygen, are practically diathermous, at least with regard to radiations which can traverse rock-salt, as we know that by far the greater part of those that we have to deal with can, such is far from being the case with other gases equally transparent with regard to light. Dr. Tyndall found that as a rule the more complex the composition of a gas the greater is its defect of diathermancy. To confine ourselves to the two gases which occur in the atmosphere mixed with its main constituents - I allude of course to carbonic acid and to water in the gaseous state of vapour-he found that both, especially the latter, which likewise is present in by far the larger quintity, are very distinctly defective in diathermancy, and he concluded that the main part of the absorption of solar heat in passing through the atmosphere, absorption as distinguished from scattering, is due to the watery vapour which it contains. From this result he drew important inferences as to atmospheric temperature and climatological conditions. Dr. Tyndall's researches on the relation of gases to radiant heat came naturally before me 
during my long tenure of office as one of the Secretaries of the Royal Society; and for my own part I may say that it seemed to me all along that the results were established on so firm a basis, and the conclusions regarding the invisible radiations were so perfectly analogous to what we know to be true regarding the visible ones, where the investigation is comparatively easy, that the work bore on it the stamp of truth. The conclusions were not, however, accepted without opposition. In the late Prof. Magnus Dr. Tyndall met a foeman worthy of his steel; a foeman, however, only in the sense of an intellectual athlete; for socially I doubt not they were the firmest friends, and their friendship was even cemented by the fact that they were both alike seeking after truth in a similar subject. But truth only gains by opposition: its defenders are led to engage in fresh researches, which end in strengthening its foundations. I think that the validity of Dr. Tyndall's results is now generally admitted. If some hesitation is still felt, it arises mainly, I think, from misconception ; from imagining that assertions which were meant to apply only to heat rays of such refrangibilities as to be absorbed by water were meant to be affirmed of the invisible radiations generally which lie beyond the extreme red. The time reminds me that I must only very briefly refer to another investigation in which Dr. Tyndall has more recently been engaged, and of which the interest is biological while the means of investigation are physical ; I allude, of course, to the question of abiogenesis. Here, again, Dr. Tyndall was working on contested ground, and the objections of opponents stimulated him to fresh inquiries, which resulted in the continual strengthening of his negative conclusions. In the course of his work he was led, for instance, to the discovery of the great difference which exists between the germs of microscopic creatures and the creatures themselves, in relation to their power of resisting the destructive influence of a high temperature. This discovery not only detected a source of error in some experiments which had seemed to favour the hypothesis of abiogenesis, but threw important light on the conditions which must be fulfilled in order to secure complete sterility. But original research is not the only way in which a man can advance the cause of science. All-important though it is, it nevertheless often happens that an original investigation is too abstruse to be followed by more than a few experts; nor is it by any means necessarily the case that an eminent investigator is equally successful in expounding to others, especially to a mixed audience, the results at which he himself or other investigators may have arrived. The general diffusion of science depends largely on the clearness with which its leading principles and results are expounded, whether by lectures or by treatises, in which, while they are scientifically sound, popularity of style and general readableness are not sacrificed to the dry exactness of scientific detail. Most of us have had opportunities, whether at the Royal Institution, with which the name of Tyndall has so long been connected, or elsewhere, of being impressed with the singularly lucid style and graphic expression with which he expounded to his audience the salient points of the scientific subject which he brought before them. Nor was it only in clearness of verbal exposition that he excelled; the manipulative skill with which his original investigations were carried on served him in good stead in his more popular expositions; and by the aid of that "domestic sun," which even the murky atmosphere of a London winter could not obscure, he was enabled in very many cases to exhibit to the audience the actual results of experiments which had first been carried out in the quiet of the laboratory. Nor is it our own countrymen alone who have had the benefit of Dr. Tyndall's lucidity of exposition. Our friends across the ocean have flocked to hear and have appreciated the lectures which he has there delivered as a free gift to
Transatlantic science. But oral lectures, after all-the lectures at least of one individual-can only reach a fraction of the community; nor do they admit of that pause for thought which the learner requires in endeavouring to make himself master of a new subject. But the same qualities of mind which enable a man to be a clear and interesting lecturer fit him also to be the author of eminently readable books; and for the general diffusion of science which is taking place we owe much to the writings of Dr. Tyndall. My lords and gentlemen, I fear that I have trespassed too long upon your time, and I will therefore now conclude by asking you once more to drink to the health of Dr. Tyndall. (The toast was drunk with great enthusiasm, the company rising.)

Professor Tyndall, on rising to respond, was received with loud cheers, the company rising. He said : -Mr. President, my Lords, and Gentlemen,-When the project of a dinner was first mentioned to me by a very old and steadfast friend of mine, who, to my regret and his, is not here to-night, had any dream, or vision, of the assembly now before me risen on my mind's eye, I should have declined the risk of standing in my present position; for I should have doubted, as I still continue to doubt, my ability to rise to the level of the occasion. Gratitude, however, is possible to all men; and I would offer you, Sir, my grateful thanks for the manner in which you have proposed this toast; I would thank with equal warmth an assembly which, in intellectual measure, is, probably, as distinguished as any of the same size ever addressed by man, for the way in which they have received it; and I would extend my thanks to my friends of the Department of Science and Art, for their spontaneous kindness to an old colleague, who for many years lent his humble aid to the Department in diffusing sound scientific knowledge among the masses of the people. My own scientific education began late. It had, of necessity, to be postponed until after I had reached the age of seven or eight and twenty. Notwithstanding this drawback, in learning, teaching, and working in the laboratory, I have been permitted to enjoy a spell of thirty-nine years. In 1850 , during a flying visit from Germany to England, I stood, for the first time, in the bright presence of Faraday. In February 1853 , I gave my first Friday evening lecture in the Royal Institution; and three months afterwards, on the motion of Faraday, the old Chair of Natural Philosophy, which had been filled at the beginning of the century by Thomas Young, was restored, and to it I was elected. It causes me genuine pleasure to think that I shall be succeeded in that Chair by so true and so eminent a man of science as Lord Rayleigh.

It is not my intention to overburden you with egotism to-night; but, casting an earnest glance back upon the past, a few words seem due from me to the memory of one or two of the group of good men, no longer with us, with whom I was so intimately associated. Regarding Faraday I will confine myself to stating that years have not altered my estimate of the beauty and the nobleness of his character. He was the prince of experimental philosophers; but he was more than this-in every fibre of his mind he was a gentleman. It is, however, of two of our honorary secretaries that I wish now to speak; premising that, for the first seven years of my life in the Royal Institution, the post of honorary secretary was held by a cultivated and very worthy gentleman, the Rev. John Barlow. From I 860 to 1873 -that is, for a stretch of thirteen memorable years - I had the happiness of working hand in hand with Dr. Bence Jones. Never in my experience have I met a man more entirely and unselfishly devoted to the furtherance of scientific work. I hardly like to mention the following incident, because it furnishes but a scanty measure of his devotion. On one occasion I was in need of funds to carry out some experiments of a delicate and 
costly character. Bence Jones came to me, and after some hesitation-for he knew that money was likely to raise a difficulty between us - he said, with earnestness : "Dear Tyndall, behave as my friend; do me the favour and the honour of devoting this to your investigation. There is more, if you need it, where that came from." $\mathrm{He}$ handed me a cheque for $£$ Ioo. Had I asked for froo, he would have given it to me, and the world, as far as he was concerned, would have been none the wiser. Bence Jones was a strong man, and liked to have his own way. At first, as was natural, we sometimes surged against each other; but these little oppositions were rapidly adjusted, and for many years before his death the tie of brother to brother was not truer or tenderer than that which united myself and Bence Jones. On my return from the United States I found him dying. In fact, the knowledge of his condition caused me to take leave, earlier than I otherwise should have done, of a people that I had learnt to trust and love. Soon after my return I saw him lowered into the grave.

The death of Bence Jones, whose steadfast loyalty to the Institution he loved so well, showed itself to the last, was a sore calamity to be met. At that time one man only seemed fitted to supply his place. That man was the beloved and lamented William Spottiswoode. To him I appealed to stand by the Institution at a critical hour of its fortunes. He had his own mathematical work on hand, and he was too well acquainted with the duties of our honorary secretaryship to accept them lightly. After much reflection, he wrote me a letter regretfully but distinctly declining the office. But he reflected a second time. He knew that his refusal would cause me pain, and his affection for me prevailed. When, therefore, the letter of refusal-for he sent it to me-came, it was accompanied by a second letter, cancelling the refusal and accepting the post. With William Spottiswoode I had the happiness of working in close companionship for six years. The diligence, wisdom, and success with which he discharged his onerous duties - the princely hospitality which shed a glow upon the office while he held it-are well remembered. Of the dignity with which he afterwards filled the high position now occupied by the illustrious man who presides here this evening it is needless to speak. Him also we have seen lowered to his rest, amid the grief of friends assembled to do honour to his memory. Such were the men who served the Royal Institution in the past; and their example has been worthily followed by other men of eminence, still happily amongst us. Never was an institution better served than the Royal Institution, and not by its honorary secretaries alone. With singleness of purpose and purity of aim, its successive Presidents, Boards of Managers, and honorary treasurers have unswervingly promoted the noble work of investigation and discovery. May they never lower the flag which, for well-nigh a century, they have kept victoriously unfurled.

The year after my appointment I was called upon to deliver, in conjunction with Dr. Whewell, Faraday, Sir James Paget, and some other eminent men, one of a series of lectures on scientific education. I then referred with serious emphasis to the workers in our coal-mines, and to the terrible perils of their occupation. I pointed to the intellectual Samsons toiling with closed eyes in the mills and forges of Manchester and Birmingham, and I said: "Give these toilers sight by the teachings of science, and you diminish the causes of calamity, multiply the chances of discovery, and widen the prospect of national advancement." Thus early, you will see, I was alive to the importance of technical education; and I am no less alive to it now. You will not, therefore, misunderstand me when I say that to keep technical education from withering, and to preserve the applications of science from decay, the roots of both of them must be well embedded in the soil of original investigation. And here let it be emphatically added, that in such investigation practical results may enter as incidents, but must never usurp the place of aims. The true son of science will pursue his inquiries irrespective of practical considerations. $\mathrm{He}$ will ever regard the acquisition and expansion of natural knowledge-the unravelling of the complex web of nature by the disciplined intellect of man-as his noblest end, and not as a means to any other end. And what has been the upshot of science thus pursued? Why, that the investigator has over and over again tapped springs of practical power which otherwise he would never have reached. Illustrations are here manifold. I might point to the industries which affiliate themselves with Faraday's discovery of benzol, and with his discovery of the laws of electrolysis. But I need not go further than the fact that in this our day a noble and powerful profession has been called into existence by his discovery of magnetoelectricity. The electric lamps which mildly illuminate our rooms, the foci which flood with light of solar brilliancy our railway-stations and public halls, can all be traced back to an ancestral spark so small as to be barely visible. With impatient ardour Faraday refused to pause in his quest of principles to intensify his spark. That work he deliberately left to others, confidently predicting that it would be accomplished. And, prompted by motives both natural and laudable, but which had never the slightest influence on Faraday, others have developed his spark into the splendours which now shine in our mid̉st.

It would be a handsome Jubilee present, if it were a possible one, to roll up the career of Faraday into portable form, and to offer it to the Queen as the achievement of one of Her Majesty's most devoted subjects during her own reign. Faraday's series of great discoveries, however, began in I831, which throws his work five or six years too far back. During the rest of his fruitful life he was a loyal son of the Victorian epoch. But, passing beyond the limitations of the individual, what is science, as a whole, able to offer, on the golden wedding of the Queen with her people? A present of the principle of gravitation-a handing over to Her Majesty of the bit and bridle whereby the compelling intellect of Newton brought the solar system under the yoke of physical laws -would surely be a handsome offering. I mention this case of known and conspicuous grandeur, in order to fix the value of another generalization which the science of her reign can proudly offer to the Queen. Quite fit to take rank with the principle of Gravitation-more momentous if that be possible-is that law of Conservation which combines the energies of the material universe into an organic whole; that law which enables the eye of science to follow the flying shuttles of the universal power, as it weaves what the Earth Spirit in "Faust" calls "the living garment of God." This, then, is the largest flower of the garland which the science of the last fifty years is able to offer to the Queen.

The second generalization is like unto the first in point of importance, though very unlike as regards its reception by the world. For whereas the principle of Conservation, with all its far-reaching, and, from some points of view, tremendous implications, slid quietly into acceptance, its successor evoked the thunder-peals which it is said always accompany the marriage of thought and fact. For a long time the scent of danger was in the air. But the evil odour has passed away; the air is fresher than before ; it fills our lungs and purifies our blood, and science, in its Jubilee offering to the Queen, is able to add to the law of Conservation the principle of Evolution.

In connexion with these victories of the scientific intellect, I have mentioned neither persons nor nationalities, holding, as Davy expressed it, when the Copley Medal was awarded to Arago, that "science, like Nature, to which it belongs, is neither limited by time nor space. It belongs to the world, and is of no country and no age." 
Still, it will not be counted Chauvinism if I say that in the establishment of these two great generalizations Her Majesty's subjects have quitted themselves like men. With regard to a third generalization, neither England nor Germany has been idle. Omitting the name of many a noble worker in both countries, the antiseptic system of surgery assuredly counts for something in the civilized world. And yet it is but a branch of a larger generalization, of momentous import, which in our day has been extended and consolidated to an amazing degree by a Gallic investigator. To some, however, any flower culled in this garden will be without odour. Let me therefore add a sweet-scented violet under the name of spectrum analysis which, besides revealing new elements in matter, enables the human worker to stretch forth his hand to sun and stars, to bring samples of them, as it were, into his laboratory, and to tell us, with certainty, whereof they are composed. Surely all these, and other discoveries of high importance, taken and bound together, form an intellectual wreath, not unworthy of Her Majesty's acceptance in her Jubilee year.

A short time ago an illustrious party leader summed up the political progress of the Queen's reign. What I have said will, I trust, show that the intellectual world is not entirely compounded of party politics-that there is a band of workers scattered over the earth whose arena is the laboratory rather than the platform, and who noiselessly produce results as likely to endure, and as likely to influence for good the future of humanity, as the more clamorous performances of the politician.

One word more. On the continent of Europe, kings had been the nursing fathers, and queens the nursing mothers, of science; while Republican Governments were not a whit behind in the liberality of their subventions to scientific education. In England we had nothing of this kind, and to establish an equivalent state of things we had to appeal, not to the Government, but to the people. They have been roused by making the most recondite discoveries of science the property of the community at large. And as a result of this stirring of the national pulse - this development of self-reliance-we see schools, colleges, and universities now rising in our midst, which promise by and by to rival those of Germany in number and importance.

It is time that I should cease. But before doing so, I would ask - as they do in the House of Commons-permission to say a word in personal explanation. I have climbed some difficult mountains in my time, and after strenuous effort for a dozen hours or more, upon ice, rock, and snow, I have not unfrequently reached the top. question whether there is a joy on earth more exhilarat ing than that of the mountaineer, who, having achieved his object, is able to afford himself, upon the summit, a foaming bumper of champagne. But, my lords and gentlemen, the hardest climb, by far, that I have ever accomplished, was that from the banks of the Barrow to the banks of the Thames-from the modest Irish roof under which I was born to Willis's Rooms. Here I have reached my mountain-top, and you-God bless you !have given me a bumper which no scientific climber ever before enjoyed.

Sir Frederick Pollock, in proposing the toast of "Literature and Art," said that on most occasions similar to the present one this toast was a triple one, and included the three sisters-Science, Literature, and Art. But this evening they were assembled together to do homage to science, in the person of one of its most distinguished votaries, and for the time the room in which they had met became a temple of science. In such a temple the principal figure, standing upon the pedestal appropriated to the presiding goddess, must be that of Science, and to her due rites had been already rendered. But for the sisters Literature and Art room must be found also in the sacred edifice; they too must have their altars and their shrines. He pointed out that the highest powers of the imagination were required by the man of science, as well as by the poet and the painter, and instanced the prediction by Fresnel of the bright spot in the centre of the shadow of a disk; and the suggestion made to Goethe of his theory of the development of the vertebrate skeleton, by his accidental observation of the scattered fragments of the deer's skull lying in his path. He adduced the names of Aristotle, Bacon, and other great men who had connected literature with science; and instanced Leonardo da Vinci, and Sir Christopher Wren, one of the founders of the Royal Society, as linking together science and art. He accordingly had great pleasure in submitting for acceptance "Literature and Art," coupling with it the name of Lord Lytton, who was not only a distinguished representative of modern literature, but had also a distinct hereditary claim to represent that of the last generation; and Sir Frederick Leighton, the distinguished President of the Royal Academy.

The Earl of Lytton,---In returning thanks for "Literature" upon an occasion when we are all met to honour science in the person of one of its most illustrious adepts, I cannot but forcibly remember that we are living in an age when inquiry is more active and more widespread than conviction, and it is natural that in minds of the highest order under these conditions even the imaginative faculty should be more powerfully attracted to scientific research than to purely literary production. But inquiry, I think, would be very sterile if conviction in some form or another were not the ultimate fruit of it, and I think that for a period of really vigorous, creative, imaginative art we must look forward in the course of scientific research to some such general re-settlement of ideas upon the basis of a common conviction-which is not now, perhaps, altogether attainable - as may enable art, instead of representing, as it does now, merely the mental attitude of the individual poet or the individual painter, once more to become the universally spontaneous and universally recognized imaginative expression of ideas and emotions which are common to a whole generation or a whole community. If that is the case, if science is ultimately to render this great service to literature and art, surely in the meanwhile we cannot but gratefully appreciate the literary labours of those men of science who in our own and in other countries are promoting or have promoted this result, not only as original discoverers but also as popular and powerful interpreters of scientific fact, and who in this latter capacity have already enriched contemporary literature with writings of rare literary value. If, instead of returning thanks for literature, I were permitted to return thanks on behalf of literature to those writers who have powerfully influenced my own generation, not only by thoughts which stimulate and instruct the intellect, but also by words which stir and elevate the heart, then assuredly I should ask leave to mention some distinguished names which occupy in the field of literature a position only second to the high rank they hold in the hierarchy of science; and foremost among those names I should not hesitate to mention with a special personal gratitude the name of the illustrious man who is the honoured guest of this great assembly to-night. I cannot say it is as a student of science that I myself have studied the writings of Prof. Tyndall, but this I can say, and most truly, that those writings have been to me, from a very early period of my life, companions so cherished that I learnt to look upon their writer as a dear personal friend and benefactor long before it was my privilege to be admitted to his personal intimacy. I believe that scientific research has succeeded in establishing on a physiological basis certain evidences of intelligence even among oysters ; and certainly there is, I think, one form of intelligence which is conspicuously displayed by the 
oyster which might perhaps be cultivated with advantage by a!ter-dinner speakers in my position. The oyster knows when to shut up. Admonished by that very interesting and suggestive fact in natural history, what little else I have to say upon behalf of literature I shall confine to the expression of a hope that the well-deserved relaxation from his more systematic scientific labours in connexion with the Royal Institution may enable my valued and honoured friend Prof. Tyndall to enjoy an increased leisure for the continued cultivation of that department of literature which has already been so richly adorned by his admirable writings.

Sir F. Leighton, who was to have responded for "Art," had been obliged to leave before this stage of the proceecings in order to receive Royal visitors at the Academy.

Sir Lyon Playfair, M.P., proposed the next toast, "The Public Services in Relation to Science." He said that undoubtedly the public services were intimately connected with science and were profoundly affected by its progress, but, unfortunately, the truth was only beginning to be recognized in this country. In the United States scientific men were attached to all public offices, but in this country the attachment was of the loosest possible character. Nevertheless, science had undoubtedly affected our public services in the most profound way. The telegraph had altered the whole system of commerce and also the methods and the powers of government. There was to be a great naval review next month; it would be interesting to imagine Elizabeth's thirty small ships, which conquered the Armada, sailing through two miles of modern ironclads. The largest piece of ordnance used in the Crimean War cost less than a single shot fired from the huge guns of our ironclads. But it was in peace rather than in war that science rejoiced in aiding government. A strong feeling was arising that we must improve our intellectual position as a nation, and this at last was being recognized by the Government. A material index of progressive civilization had always been desired. Liebig contended that the best index of civilization was the quantity of soap consumed. When the Queen ascended the throne we consumed per head $7 \frac{3}{4}$ pounds of soap, and now we use Io pounds per head. The consumption of paper was a more reliable index. At the commencement of the Queen's reign the consumption was $I_{1}^{\frac{1}{4}}$ pound of paper yearly; now it was 12 pounds; while in the United States it was ro pounds, in Germany 9 pounds, in France 8 pounds, and in Italy 4 pounds. But the main question was whether we were developing the national intellect at the same rate as other nations. Our general intelligence is still high, but our trained scientific intelligence is low. Our secondary education in all matters relating to science was far behind that of the United States, Germany, and France. Nei.her the Government nor the people governed could go on in simple faith on our practical aptitudes by relying on a blind and vain empiricism, like a tree severed from its roots.

The Earl of Derby,-My Lords and Gentlemen : You have asked me to return thanks on behalf of the public services in connexion with science, and Sir L. Playfair, in relation to that toast, has referred to the increased consumption of soap in this country. I have attended a good many public dinners, and I must say that the expenditure of what is vulgarly called soft soap has been great this evening. I am sincerely grateful to him for the quantity of that article which it has pleased him to expend upon me. But really the toast is one which hardly any man is competent to do justice to, and certainly not one who like myself has no connexion with science, except a sincere admiration and respect for its professors, and whose connexion with the public service has only been that of a Parliamentary chief. Under our system the Parliamentary head of a department is mainly concerned to keep it in harmony with the House of Commons and with the public. He has to warn the permanent officials that something that is done, or something that is left undone or proposed to be left undone, is what public opinion will resent; and, on the other hand, he has to tell outsider that the things they ask him and press him to do are things unwise or impossible from an administrative point of view. That is useful ; it is certainly laborious, and it is often a difficult function; but it does not involve much more scientific knowledge than is implied in driving a cab through a crowded street. It does require some knowledge of men, but that is a department of study to which, as yet, no scientific formula has been found to apply. Sir L. Playfair told us, and I was sorry to hear it, of the loose connexions which exist between science and the Government. I can only say that I am entirely ignorant of any such immoral transactions. But if the departments were better represented here and if they could speak for themselves, I am sure that they would not be backward in acknowledging their obligations to science. The Treasury would tell you that those useful though sometimes ungraceful coins in which our dinner is paid for would not circulate through Europe as they do if they had not been subjected to a careful and complicated process, requiring scientific knowledge. The Excise might tell you, if they chose, of the frauds that might be perpetrated upon the revenue and the public if it were not for the careful and scientific examination of all taxable articles. The Post Office would find no difficulty in acknowledging its obligations to Watt and to Stephenson-for where would postal revenue be without railways?--and in later days to investigators whose researches made the telegraph possible. But the fighting departments, or the spending departments, which is their more common name in Downing Street, would have the most to return thanks for. They would point to the modern ironclad, the most elaborate, the most complete, and the most costly, of all contrivances in which the art of construction has been utilized for purposes of destruction. They would tell you how the chemist, metallurgist, the engineer, the electrician, the mathematician, have all contributed their share to that extraordinary result of science and skill. The War Office would follow the Admiralty. They would not say, as Frederick of Prussia did, that Providence is on the side of the biggest battalions, but they might possibly say that Providence was generally on the side of the army which could bring into the field the most scientifically effective weapon in the hands of the most carefully-trained soldier. If I were to turn to the line of business with which I had once something to do, I might ask any diplomatist or any statesman to explain to you how largely the position of Egypt, and, with that, the diplomacy of Europe, has been affected by that little scratch which the genius of M. de Lesseps drew across the Egyptian sands; and if, as is quite possible, the coal-carrying power of steamers and their speed and their economy are largely increased-I do not speak of those wilder predictions according to which steam is to be superseded as the motor fower by something more efficient--suppose I say the large increase of the coalcarrying power of steamers, and the results to which I have referred may be again reversed ; and again, at least in war time, the route to India may lie through the South African seas. If I speak of the colonies, everyone conversant with that department would admit that if we had had the ocean telegraph in existence twenty-five years ago half our little wars beyond the seas would never have taken place, and those that have taken place would bave been disposed of in half the time. I know that these things are common-place, but I cannot help that. If I could tell you what the next great discovery was going to be, that would not be common-place. But, unfortunately, that is not in my power; and if it were I do not think I should be in a hurry about it, because I have observed that those who are the first to announce a discovery are generally rewarded by having a remarkably unplensant time. But however great may be the gains which we 
have derived from the applications of science, they are nothing as compared with those which will and do accrue to us from the acceptance of scientific habits of thought. That is coming already, and it will come more in a not remote future. We have many things in this age and country of which we cannot boast, but we may boast that in science England has done something more than hold her own. The great name of Darwin will survive, it may be, the British Empire itself, and with him will be remembered some others also, whom to single out might perhaps be invidious. But we may be sure of this, that among their names will be included the name of our distinguished guest of to-night. It is a common complaint that politicians have done nothing for science. In that I do not agree. They have done the best they could for it -they have let it alone; they have not corrupted it by their intrigues, nor vulgarized it by their squabbles; and they being what they are, and science being what it is, that is probably the best service they could have rendered it.

Lord Rayleigh proposed "The Health of the Chairman."

Prof: Stokes briefiy responded, and the company, which numbered nearly two hundred, separated.

\section{THE ELEVEN-YEAR PERIODICAL FLUCTUA-} TION OF THE CARNATIC RAINFALL.

MORE than fourteen years ago, in the pages of I NATURE, Mr. Normun Lockyer first drew attention to an apparent periodical variation of the rainfall registered at the Madras Observatory; which seemed to be such that it reached a maximum and a minimum alternately, at about the same epochs as the corresponding phases of the sunspot frequency. The idea, once started, was followed up by others, among whom perhaps the best known is Dr. (now Sir) W. W. Hunter, whose pamphlet on the subject, without laying claim to any originality as regards its subject-matter, attracted very general attention by the charm of its style, and also by its attempt to identify the periodical occurrence of famines in Southern India with the epochs of minimum rainfall shown by the Madras registers.

When, however, the data on which these speculations were based came to be critically examined, the general verdict of men of science was that the conclusions were "not proven." This was certainly my own opinion; and General R. Strachey, in a lecture delivered before the Royal Institution in 1877 , and, at greater length, in a paper communicated to the Royal Society in May of the same year, showed that any attempt to educe a true cyclical variation from the recorded figures, ended in a negative result. Admitting that when the annual quantities were tabulated in eleven-year cycles, the means of the homologous terms seemed to indicate a period of maximum between the third and seventh years, and of a minimum between the eighth and second years, he found that, when the mean difference of the individual years from the supposed periodical means was compared with the mean difference of the former from the arithmetical mean of the whole series, the results differed but little.

It was further shown by myself that the supposed connexion between the periodicity of the Madras (Observatory) rainfall and that of famines in Southern India was by no means so intimate as might appear at first sight. The famines in question had occurred sometimes in one part of the peninsula, sometimes in another, by no means always in the country around Madras; but no other station in the peninsula (of those then available for the inquiry) showed even such an approach to a periodical variation of the rainfall as did the Madras Observatory.

At this stage matters have since remained, with the exception that, in 1879 , an apparent periodical fluctuation of a very different character was brought to notice by Messrs. Hill and Archibald in the winter rainfall of
Northern India. This, which has an interest of its own, I shall not further discuss at present.

In the course of a general investigation of the rainfall of India, the first part of which only has been as yet published ("Indian Meteorological Memoirs," vol. iii. part I), I have lately had occasion to reconsider these old questions, and to re-examine them by the light of the accumulated data of the last twenty-two years. For convenience of discussion, I have divided India and Burmah into twenty-four rainfall provinces, one of which is the Carnatic.

This consists of the plain below the Eastern Gháts, occupying the south-east of the peninsula, and extending from Cape Comorin to the mouths of the Kistna. Its area may be taken as 72,000 square miles. The town of Madras is situated nearly midway on the sea-coast of this province, and is a fairly representative station; but, in addition to the rainfall registers of the Madras Observatory, I have those of thirty-nine other stations, pretty equally distributed through the province; most of them extending back to I864. The Carnatic is distinguished by one important peculiarity in the season of its chief rainfall. During the spring months, it receives a certain amount of rain, in common with the southern and eastern provinces of India generally; but while the heavy summer rains are falling in Central and Northern India, and also on the west coast of the peninsula, the Carnatic is but little affected by them. In its southern districts, indeed, the rainfall of June and July is less than that of May; and it is not until the rains are over in North-Western India, viz. in October and November, that this province receives the chief and heaviest rainfall of the year. Hence the vicissitudes of the rainfall of the summer months, which are all important in Central and Northern India, are relatively less important in the Carnatic, even if they affect that province in the same manner as Northern India-and this is far from being always the case--and as a final result the annual fluctuation of the Carnatic rainfall often differs widely from that of other provinces in the peninsula.

'The mean annual rainfall of the Carnatic may be taken in round figures at 35 inches, which is about 7 inches less than the general average of the whole of India. The following table gives the annual variation from this average for the twenty-two years $1864-85$, which results when the annual total fall of each individual station is compared with its local average, and the mean of all the differences taken for each year.

$$
\begin{aligned}
& \text { Annual mean rainfall variation of the Carnasic rainfall. }
\end{aligned}
$$

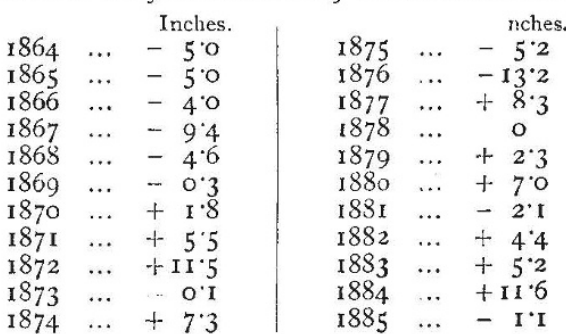

During the first thirteen years (with the exception of 1873) the fluctuation, here shown, is remarkably distinct and regular. The rainfall reached a minimum in 1867 , then rose steadily to a maximum in 1872 , and after a drop in 1873 , and partial recovery in the following year, fell rapidly to a second minimum in 1876 . From 1877 to I 88I it oscillated considerably, but thereafter rose again steadily to a second maximum in 1884 , dropping again in I 885 to something below the average. Thus we have, apparently, two complete cycles in the twenty-two years; the first remarkably regular, the second less so, but with the periodical fluctuation still dominant.

In order to ascertain with somewhat greater precision 